\title{
Metaplastic Breast Carcinoma
}

National Cancer Institute

\section{Source}

National Cancer Institute. Metaplastic Breast Carcinoma. NCI Thesaurus. Code C5164.

A group of invasive breast carcinomas characterized by the presence of an

adenocarcinomatous component which is admixed with a dominant component that is composed of squamous cells, spindle cells, or mesenchymal cells. 